\title{
ANALYSIS OF AID GUIDELINES AIMED FOR DEVELOPMENT OF BUSINESS ENVIRONMENT ATTRACTIVENESS IN PIERIGA REGION
}

Baiba Rivza' ${ }^{1}$, Dr.habil.oec., prof.; Ligita Azena ${ }^{2}$, Mg.sc.soc.

1,2 Latvia University of Life Sciences and Technologies,

Abstract. Support for development of business environment is oriented to attract local and foreign investments, promote creation of new businesses and support existing ones, create new jobs and decrease the flow of workforce to other territories. It is important to tailor territorial support guidelines to each individual territory, thus defining the direction of its development and potential specialisation. The study aims to analyse aid guidelines aimed for development of Riga Planning Region business environment attractiveness. The tasks of the study were to: 1 ) establish the business environment support guidelines according to Sustainable Development Strategy of Latvia until 2030 and regional political guidelines 2013-2019; 2) analyse business environmental aid guidelines, which are defined by the Riga Planning Region (henceforth - RPR) development programme 2014 - 2020 and strategic programmes of Pieriga region. Research method: document analysis.

Keywords: territorial development, regional developmental support guidelines, regional business environment. JEL code: 011,018

\section{Introduction}

Development of large cities dictates the need to increase the economic activity in these territories, by attracting resources of nearby territories, supporting entrepreneurship, development of transportation and Information and Communication technology (ICT) infrastructure, developing the potential of education institutions and promoting the mobility of workforce. This promotes creation of new businesses and jobs, stimulating living and working near large cities.

Territorial support guidelines:

1) development of business infrastructure (industrial areas, transport and communication infrastructure for business territories, resort areas etc.) according to the territorial specialisation as per regional municipalities guidelines;

2) availability of quality services in line with a set of publically available individual services according to the type of international, national and regional development centre;

3) maintenance and development of transport infrastructure, including service and job accessibility for people living in the regions (Regional Policy Guidelines, 2013-2019)

The most significant common regional development problem, characteristic of the whole country is the disparities in socioeconomic development between different regions. This is due to several reasons. Primarily, this is caused by low business activity and incomplete prerequisites to increase it in the regions. A significant problem is inadequate regional government infrastructure and the lack of regional government capacity to work with entrepreneurs. At the same time, due to insufficient mandate, regional governments lack the freedom to carry out flexible solutions considering individual situations, including available resources and territories, when attracting entrepreneurs.

The study aims: to analyse aid guidelines aimed for development of the Riga Planning Region business environment attractiveness. To achieve the goal, it was put forward: 1) to find out what the business environment supporting guidance is set in Sustainable Development Strategy of Latvia until 2030 and Regional Policy Guidelines 2013- 2019; 2) to collect business environmental aid guidelines, which are defined by Riga Planning Region (hereinafter - RPR) Development Program 2014-2020 and Pieriga region's strategic and action programs. Research methods: analysis of documents. 
Hypothesis - business environmental aid guidelines are the basis of areas of specialization and economic development of Latvia. The object of the research - strategic document analysis. The authors set research objectives: 1) to analyse strategic documents related with the business environment aid guidelines RPR; 2) to assess achievable RPR economic indicators and profiles based on business environmental aid guidelines.

\section{Material and methods}

The Ministry of Economics of Latvia (henceforth- LR EM) has issued a report on business and environment. According to this report, based on provisional data for 2016, there were 129 . 12 thousand economically active individual merchants and commercial companies in Latvia (excluding farmer or fishermen companies and self-employed persons). $99.6 \%$ of the above can be categorised as small or medium-sized enterprises (henceforth SME). Division of SMEs in Latvia is as follows: microenterprises - $89.6 \%$, small enterprises $-8.9 \%$, medium-sized enterprises$1.5 \%$. A significant indicator of economic activity is the number of enterprises per 1000 people. In the last 10 years, this number has steadily increased from 17 in 2001 to 83 in 2014 (LR EM, 2016.)

In Latvia, just like elsewhere in Europe, SMEs significantly contribute to economy, GDP, unemployment rates.

In 2016, more than half (54.6\%) of economically active market sector statistical units were operating in RPR; 54.6 individual merchants and commercial companies per 1000 inhabitants, yet in other planning regions this is number was 2 to 3 times lower. In 2016, $68 \%$ of jobs in the country were in RPR according to the Central Statistical Bureau of Latvia (henceforth - CSP) data. Regions outside Riga have a significantly larger number of self-employed persons (in RPR - $24 \%$, other regions $-40-52 \%$ ) and individual merchants, as well as a significantly higher unemployment rate (in the beginning of 2013 RPR $4.9 \%$, other - 7.4-13.7\%), giving evidence of the lack of employers in the regions.

A significant factor that directly impacts the socio-economic development in the regional municipalities is availability (the upkeep and accessibility of transport infrastructure). According to the Latvia Ministry of Transport and Communications data, approximately $50 \%$ of paved roads where in poor or very poor state (including $48.1 \%$ of the main roads, $54.3 \%$ of the regional roads and $47.3 \%$ of the local roads ( 2011 data). $25 \%$ or $2069 \mathrm{~km}$ of paved roads can be classified as collapsed and in need of complete reconstruction (2010 data). This condition of transport infrastructure limits workforce mobility, thus making territories further away from the capital unattractive to live or carry out business (transportation of manufactured goods to the retailer, wholesaler or larger transportation hubs (rail, port etc.) is problematic and requires a significant amount of time etc.) (RPR, 2010).

Although Riga is significantly more developed than other Latvian cities, compared to similar cities in the neighbouring countries the development indicators are not too high. Riga GDP (PPP) per capita is $90 \%$ of the average level of the Baltic Sea region capital cities scoring lower than Tallinn, in which this indicator is $96 \%$. This shows an untapped development potential - it is essential to promote development of Riga and other regional cities at a political level, thus driving economic activity, innovation development, improve accessibility of services (Riga as the main driving force of Latvia national development and other regional towns' development driving force of Latvian regions). 
In the Sustainable Development Strategy "Latvia 2030", specific issues and challenges as well as a multitude of opportunities for development have been laid down. In the Riga Metro area (Pierigas region), the present development of transport and road infrastructure has not been able to keep up with a sharp increase of traffic. Between 2003 and 2016, the population of Riga planning region has increased by $2.6 \%$ (CSP provisional data), thus increasing the workload to infrastructure. In the meantime, there is a trend to move from Riga to the neighbouring regions with Riga remaining only as a place to work, study and spend leisure time. This is a reason for an increased traffic flow to and from the capital. Between 2000 and 2010, the number of privately owned vehicles in Riga has increased by more than $60 \%$. In the last 10 years, the number of vehicles entering Riga every day has doubled. This causes visible traffic congestion, decreasing the movement of workforce and tourists, increasing environmental pollution. Therefore, Riga city and surrounding territory infrastructure requires development as well as improvement of public transportation system.

In Latvia regional policy, new target territories or territorial focus has been placed to promote business development and investment in the regions, emphasising involvement of many parties to achieve regional political goals (Latvia- 2030).

\section{Research results and discussion Improvement of business environment in local and regional levels}

In promotion of regional development, the most significant aspect is economic activity creation of businesses and jobs to provide employment opportunities and associated wealth for local inhabitants. This decreases the risk of depopulation as well as provides income for regional governments in form of taxes. Increased income from taxation allows to invest in development of infrastructure thus increasing overall quality of life. Territorial development from the economic point of view is a fight for growth resources (human resources, investments etc.) to acquire the critical mass of resources for development.

To create prerequisites for economic development at the local and regional levels, the following activities will be carried out:

1) Identification of available resources and specialisation of a certain territory;

2) Territorial recognition - branding and marketing linked to local initiatives and specialisation, thus creating a uniform and easily recognisable territorial identity;

3) Regional municipalities will be provided with investments to assist with maintenance and development of infrastructure and to attract local and foreign investment, thus promoting creation of new businesses and expansion of current businesses in regions;

4) Increase the capacity of regional governments and planning regions to promote innovative entrepreneurship with high added value and the efficient and creative use of local resources (emphasis on "small" innovations and everyday creativity, per "Latvia 2030" guidelines);

5) Improvement of business environment at a local scale, including reduction of bureaucracy and administrative burden etc. (Latvian regional economic development prospects and trends from 2014 to 2020).

The task that is closely related to service and business development is that maintenance and improvements of transport infrastructure providing accessibility of jobs and services and allowing businesses easily transport their production etc. The issue of accessibility can be solved also by 
reducing the need to commute in certain situations (e-services, distance working etc.) (Law on the National Industrial Policy Guidelines for 2014 to 2020).

\section{Support for Riga planning region}

The aim: to create all the prerequisites for RPR to become a Northern European metropolis, this is attractive to live in, to invest in, and to travel to. Riga successfully functions as part of the Baltic Sea region, thus increasing the global competitiveness of the whole macro region.

Support directions:

1) Improvement of state transport infrastructure, making Riga more accessible;

2) Improvement of transport infrastructure and public transportation system in the Riga city;

3) Reconstruction and development of multifunctional objects in Riga to promote cultural, sport and other events of national and international scale, promote tourism and resort development.

\section{The role of regional governments and planning regions in the business development}

As mentioned above, at the present moment business activity is largely concentrated in the capital city and the surrounding territories, which suggests that resources in the regions are underused and there is a potential for development. The activity of the public sector to attract local and foreign investment and to develop economic activity is fragmented and insufficiently effective at the moment. Institutions at the national level lack detailed information of specific issues problems and potential of each individual territory. For this reason, national support mechanisms cannot efficiently promote business development in the regions. Involvement of regional governments is necessary because they are the most aware of the local specifics and situation. Because of this, the role of local and regional level to promote economic activity will be increased.

To promote the increase of economic activity, an efficient use of available resources, the following actions will be taken during the guideline development. To enhance the role of regional municipalities in business promotion, it is necessary to:

1) Improve laws and regulations, to allow greater freedom for regional governments to manage their property and resources for the common interests of the local communities;

2) enhance and diversify the options for local governments to support entrepreneurs;

3) increase the capacity of local governments to attract investment (incl. support for events at a local and regional scale to attract investors and promote small innovation in the territories);

4) Improve the business environment in regional governments, including lessening of the state administrative burden for entrepreneurship. (RPR, 2014).

\section{The business card of Riga planning region}

RPR is the region of the capital city of Latvia. Geographical location in the centre of Baltic States and on the border of European and eastern cultures has carved Riga region as a bridge between different countries and their people. The region is characterised by the dynamic capital city of Riga, organically including influences from different nations. Other cities of the region - Jurmala, Limbazi, Tukums, Ogre and Sigulda - as well as the pure countryside, are important as well. Riga Gulf of the Baltic Sea and the long coastline as well as the inner waters are of special value to the region. (Fig. 1)

Socio-economic, technological, and scientific development is defined by the centre of national, international, and European importance - Riga city and Riga Metropolitan area. The functional 
space of the region significantly exceeds the physical borders of the region. Strategically significant geographical location of the region, high ability of inhabitant attraction and comparatively large market capacity form the economic potential of the region promote national development. The most important elements of cultural, educational, scientific, sport, healthcare, and transport infrastructure of the state are concentrated in the Riga Metro region. RPR economic indicators are shown in Table 1.

Table 1.

Pieriga planning region economic profile

\begin{tabular}{|c|c|}
\hline Territory & Local governments 30 \\
\hline & Regional centres 4 Tukums, Ogre, Sigulda, Limbazi \\
\hline \multirow[t]{2}{*}{ Inhabitants } & Population(2017) $1097419 \quad$ Net population change (2017) $-1,9 \%$ \\
\hline & Population density $105 \mathrm{ppl} / \mathrm{km}^{2}$ \\
\hline \multirow[t]{2}{*}{ Economic } & IKP (2014) 16154 EUR per capita. Income tax (2014) 585 EUR/pers. \\
\hline & Number of enterprises (2015) 106882 \\
\hline
\end{tabular}

Source: author's calculations based on statistics (CSP, RPR, 2017)

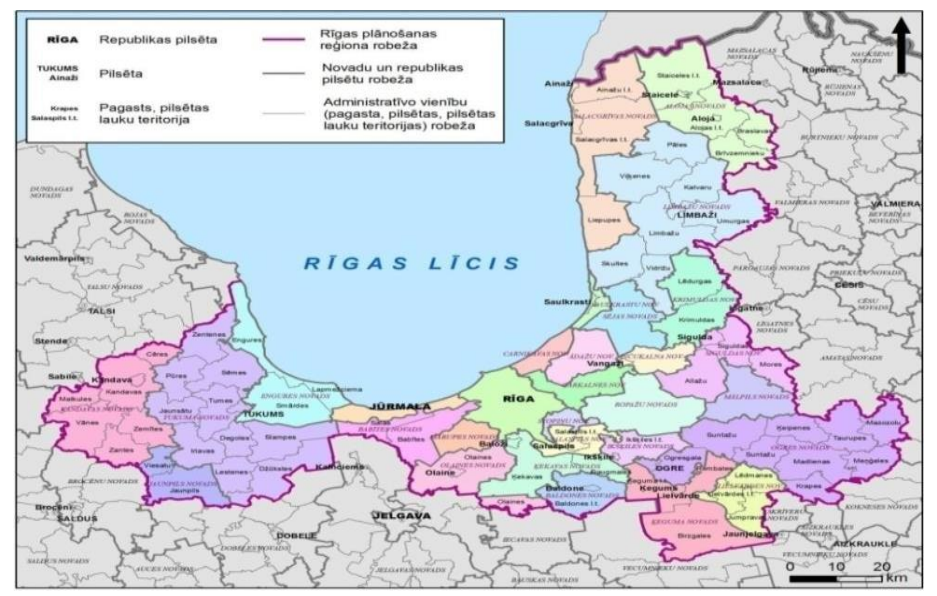

Fig. 1. Administrative division of Riga planning region (RPR)

RPR Sustainable Development Strategy 2014-2030 and RPR Development Programme 2014-2020 are framed by thee strategic goals:

1) Socially inclusive cohabitation of prosperous communities;

2) Knowledge-based, green, innovative and elastic economy;

3) Ecologically tolerant lifestyle and environment;

and eight linked and mutually integrated long- and medium-term priorities:

1) Vital natural movement and migration;

2) Self-sufficient communities;

3) Elastic and excellent education;

4) Globally competitive business areas;

5) Excellent traffic organisation, infrastructure and logistics;

6) Regional governments push for development;

7) Sustainable living environment;

8) Smart development.

RPR economy is dominated by service businesses with the associated areas - sales, professional services, property market. Each of these areas individually makes up more than $10 \%$ of the total 
economy of Riga region. Sales come close to a quarter. Significant portions in the total economy are taken up by agriculture, construction, and transport and storage businesses. Processing manufacturing take up $6 \%$ of the total economy of Riga region (RPR, 2014).

Based on the data of the State Regional Development Agency, RPR exhibits more optimistic indicators of economic development than the rest of the country. For example, nationwide unemployment rate in the beginning of 2013 was $7.278 \%$, whereas in the RPR this figure was only $4.9 \%$. According to the Central Statistical Bureau data, RPR has the highest average wage in the country. The average wage reached a low point in 2010, following the economic crisis of 2008 when it was 633 EUR/month nationwide and 700 EUR/month in the RPR. In 2013, wages had risen to 785 EUR/month in Riga and 716 EUR/month nationwide (RPR, 2014)

- Each Riga and Riga region territory has its own characteristics and specific traits and issues. Some of these are the following:

- Potential of regional centres significantly exceeds the potential of other small towns;

- High concentration of workforce, business activity, other economic and social activity;

- Large number of economically active businesses, relatively low unemployment, large amount of foreign investment;

- Availability of services (education, culture, knowledge, social, healthcare and other areas). RPR generates 2/3 of the whole GDP. Objective positions of RPR in Latvia are directed by regional specialisation in provision of services, such as education, healthcare, government, finances and sales. There are some areas that are localised due to historical reasons and not because of the "capital city effect", such as woodworking, chemical manufacturing, metalworking, tourism. RPR economic indicators and expected specialisation trends are shown in Table 2.

Table 2.

RPR economic indicators and specialisation, expected trends

\begin{tabular}{|c|c|c|c|c|c|}
\hline \multirow{2}{*}{ Parameter } & \multicolumn{2}{|c|}{ Base value } & \multirow{2}{*}{2016} & \multirow{2}{*}{2020} & \multirow{2}{*}{2030} \\
\hline & Year & Value & & & \\
\hline Population & 2013 & 1090303 & $1.1 \mathrm{mil}$ & $1.05 \mathrm{mil}$ & $1.1 \mathrm{mil}$ \\
\hline Rate of natural increase & 2012 & -2563 & -2000 & -1500 & 0 \\
\hline Net migration & 2012 & -3816 & -2500 & 0 & +2500 \\
\hline Average wage (EUR) & 2013 & 785 & 850 & 1000 & 1200 \\
\hline Unemployment ( \%) & 2013 & 4,9 & $\leq 5 \%$ & $\leq 5 \%$ & $\leq 5 \%$ \\
\hline GDP per capita (EUR) & 2010 & 11690 & $+5 \%$ & $+7 \%$ & $+10 \%$ \\
\hline $\begin{array}{l}\text { Economically active statistical units of the } \\
\text { market sector }\end{array}$ & 2011 & 77662 & $+5 \%$ & $+15 \%$ & $+30 \%$ \\
\hline $\begin{array}{l}\text { Number of active innovative manufacture } \\
\text { and service businesses }\end{array}$ & $2008-2010$ & 692 (LV) & $+5 \%$ & $+15 \%$ & $+30 \%$ \\
\hline $\begin{array}{l}\text { Territories of special status to help join } \\
\text { high technologies, manufacturing, research } \\
\text { and education } \\
\text { (business parks, incubators, knowledge } \\
\text { transfer centres etc.) }\end{array}$ & 2013 & $100(\%)$ & $+30 \%$ & $+50 \%$ & $+30 \%$ \\
\hline
\end{tabular}

Source: authors' calculations based on the data from Riga planning region development programme 2014-2020

Significant transport, energy, environmental, communication and information infrastructure is concentrated in Riga region. Transport infrastructure is of extreme significance - Riga port, Riga international airport, railway links, motorways, energy and power infrastructure, gas pipes and underground gas storage facilities. Investments in infrastructure are important to increase the competitiveness of the state and attract further investments. It is important to view the 
infrastructure as a whole when planning funding for maintenance and development. Supporting infrastructure may differ depending on the location and investor requirements.

Business profile of Riga and other cities of the region:

- Service and business centre function;

- Different types of manufacturing agricultural products, light industry, metalworking, woodworking;

- Logistics, storage, transportation and communication hubs;

- Mining and processing of minerals;

- Recreational activities, tourism;

- Property business, construction.

\section{Conclusions}

1) In Latvia regional policy, new target territories, or territorial focus have been placed, to promote business development and investment in the regions, emphasising involvement of many parties to achieve regional political goals.

2) The most important aspect to promote regional development is the economic activity - creation of jobs and businesses because they provide employment opportunities and associated prosperity to the local inhabitants. This decreases the risk of depopulation as well as provides income for regional governments in form of taxes. Increased income from taxation allows to invest in development of infrastructure thus increasing overall quality of life.

3) Prerequisites for business environment development:

- Identification of areas of existing resources and specialization (regions - economic profile) determination and strength - RPR location close to the capital, infrastructure, education, economically active population and young people in large proportion;

- the territory reputation - brand building and marketing strategy in accordance with Riga and Pieriga territory of the territorial coverage of the characteristics and specificities;

- investments in business support infrastructure development and improvement in accordance with Riga and Pieriga site characteristics and specificities;

- measures to promote innovative business development in the promotion - the areas of specialization, business education, youth involvement in entrepreneurship;

- improvement of business environment at local level, including reducing the administrative burden on operators' responsible specialist attraction in municipalities etc.

4) To promote entrepreneurship regional governments, need :

- local governments greater rights to dispose of public property, and it holds the front of agreement and common interest of the local community - industrial zones;

- to expand and diversify the local opportunities to support entrepreneurs, including collaborative efforts - municipal and private partnership in developing joint projects (housing stock, educational institutions etc.).

- to increase the capacity of local governments to attract investments - active use and encourage traders to use the EU funds;

- improving the business environment in municipalities and regions, including reducing of the state and local municipalities imposed administrative burdens on business - to conduct training courses for entrepreneurs. 
5) RPR exhibits more optimistic indicators of economic development than the rest of the country, which provides wider opportunity to improve the business environment. Riga region is the hub of transport, power and energy, environmental, communication and IT infrastructure.

6) Each RPR territory has a defined area, characteristics and specific issues.

7) It is important to evaluate the supporting infrastructure, depending on location and associated specificity, to plan the specialisation of a territory in the business environment development guidelines.

\section{Acknowledgements}

Research supported from National Research programme EKOSOC-LV and Riga Planning Administration (RPR)

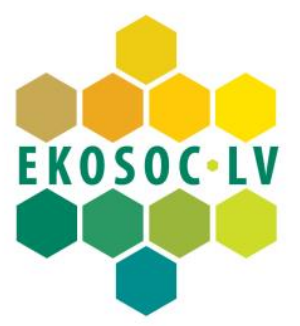

\section{Bibliography}

1. Competiveness Analysis of Pieriga Region of Latvia. Presentation at the 1st International Conference "Trends in Regional Development in the EU Countries 2015", Riga 2015.

2. (CSP) The Central Statistical Bureau (Centrālā statistikas pārvalde). Available on the Internet: http://www.csb.gov.Iv/statistikas-temas/metodologija/iedzivotaju-skaits-un-galvenie-demografiskieraditaji-36803.html>.

3. Sustainable Development Strategy of Latvia until 2030 (Latvijas ilgtspējīgas attīstības stratēǵijas līdz 2030.gadam). Available on the Internet:

<file:///C:/Users/home/Desktop/pasvaldiba/pieprigas_planosanas_parvalde/Latvija_2030.pdf> (02.01.2017.).

4. Latvijas ilgtspējīgas attīstības pamatnostādnes. Available on the Internet: http://varam.gov.Iv/files/text/Darb_jomas//pamatnostadnes. doc.

5. LR Ministry of Economy Report on the Business Environment (LR Ekonomikas ministrijas zinojums par uznēmējdarbības vidi). Available on the Internet: https://www.em.gov.Iv/lv/nozares_politika/nacionala_industriala_politika/uznemejdarbibas_vide.

6. Law on the National Industrial Policy Guidelines for 2014 to 2020 (Likums par Nacionālās industriālās politikas pamatnostādnēm 2014.-2020.gadam). Available on the Internet: http://likumi.lv/doc. php?id=257875.

7. Rgional Development of Latvia 2011 (Reǵionu attīstība Latvijā 2011). Vides aizsardzības un reǵionālās attīstības ministrijas Valsts reǵionālās attīstības aǵentūra. Available on the Internet: http://www.vraa.gov.lv/lv/parskats/parskats2011.

8. Regional Policy Guidelines 2013- 2019 (Reǵionālās politikas pamatnostādnes 2013.-2019.gadam). Available on the Internet:

file:///C:/Users/home/Desktop/konferences/promocijas_darbs/materiali/regionu_pamatnostadnes \%20(1).p df.

9. Riga Planning Region Development Program 2014 - 2020 (Rīgas plānošanas reǵiona attīstības programma 2014 - 2020). Available on the Internet:

file:///C:/Users/home/Desktop/pasvaldiba/pieprigas_planosanas_parvalde/RPR \%20AP \%20Projekts_15.sep . pdf.

10. Riga Planning Region's Economic Profile (Rīgas plānošanas reǵiona ekonomikas profils). Available on the Internet:

file://C:/Users/home/Desktop/pasvaldiba/pieprigas_planosanas_parvalde/RPR \%20Ekonomikas \%20profils. pdf.

11. Riga Planning Region Sustainable Development Strategy 2014 - 2030 (Rīgas plānošanas reǵiona ilgtspējīgas attīstības stratēǵija 2014 - 2030). Available on the Internet:

file://C:/Users/home/Desktop/pasvaldiba/pieprigas_planosanas_parvalde/RPR \%20AP \%20Projekts_15.sep . pdf.

12. Riga Planning Region of the Current Situation Description and Analysis (Rīgas plānošanas reǵiona pašreizējās situācijas raksturojums un analīze). Available on the Internet: 
Proceedings of the 2018 International Conference "ECONOMIC SCIENCE FOR RURAL DEVELOPMENT" No 48

Jelgava, LLU ESAF, 911 May 2018, pp. 220-228 DOI 10.22616/ESRD.2018.088

file://C:/Users/home/Desktop/pasvaldiba/pieprigas_planosanas_parvalde/RPR \%20Pasreizejas \%20situacij as $\% 20$ raksturojums.pdf. 